Int. J. Electrochem. Sci., 12 (2017) $4291-4300$

\title{
Development of an Electrochemical Biosensor for Rapid Detection of Foodborne Pathogenic Bacteria
}

\author{
Yi Wu and Hui Chai \\ College of Life Science, Zhejiang Chinese Medical University, Hangzhou 310053, P.R. China \\ *E-mail: huichai_zcmu@126.com
}

doi: $10.20964 / 2017.05 .09$

Received: 29 January 2017 / Accepted: 6 March 2017 / Published: 12 April 2017

The development of quick, sensitive and targeted approaches to detect foodborne pathogenic bacteria is very critical to the implementation of efficient practice to guarantee food security. We reported the results of research relevant to fabrication of the graphene wrapped copper (II) assisted cysteine hierarchical structure (rGO-Cu(II)) synthesised under moderate, aqueous as well as eco-friendly conditions. A super sensitive unmarked electrochemical immunosensor for quantitative assay of Staphylococcus aureus has been formed with the use of $\mathrm{rGO}-\mathrm{Cu}(\mathrm{II})$ as the sensing layer..

Keywords: Pathogenic bacteria; Graphene; Nanocomposite; Staphylococcus aureus; Immunosensor

\section{$\underline{\text { FULL TEXT }}$}

(C) 2017 The Authors. Published by ESG (www.electrochemsci.org). This article is an open access article distributed under the terms and conditions of the Creative Commons Attribution license (http://creativecommons.org/licenses/by/4.0/). 